UDC 378.147:004.42-051

DOI: https://doi.org/10.31470/2415-3729-2020-12-184-197

\title{
Approaches to Taking Into Account Cognitive Styles in the Process of Professional Training of Future Software Engineers
}

\author{
Andrii Sender \\ Post-graduate student of the Department of Informatics and \\ Cybernetics, \\ Bogdan Khmelnitsky Melitopol State Pedagogical University \\ $\triangle 20$, Hetmanska Str., Melitopol, Zaporizhzhia region, Ukraine, \\ 72312 \\ E-mail: sender@mdpu.org.ua \\ ORCID: http://orcid.org/0000-0002-8741-5625
}

Date of receipt of the article: September 28, 2020

Article accepted for publication: November 22, 2020

\section{Підходи до урахування когнітивних стилів у процесі професійної підготовки майбутніх інженерів-програмістів}

\section{Андрій Андрійович Сендер}

аспірант кафедри інформатики і кібернетики, Мелітопольського державного педагогічного університету імені Богдана Хмельницького

$\square$ вул. Гетьманська, 20, м. Мелітополь, Запорізька обл., Україна, 72312

Дата надходження статті: 28 вересня 2020 р. Стаття прийнята до друку: 22 листопада 2020 р. 


\section{Abstract}

The article presents the results of a study aimed at analyzing the psychological phenomenon of «cognitive personality style».

The research goal is to determine approaches to taking into account the cognitive styles of future software engineers in the process of professional training in educational programs of master's level.

Methods. Basic research methods used were search and selection of relevant articles on the research problem in the Google Scholar search engine and bibliographic abstract database Scopus; analysis and generalization of scientific publications; study of the educational process.

The results. The scientific publications on the problem of cognitive personality styles are analyzed. The modern interpretations of this concept and its characteristics are considered. In particular, it is established that cognitive style is a well-established individual ways of intellectual behavior of the individual. It is shown that the consideration of cognitive styles is important for achieving the goals of training future software engineers in master's degree programs, as one of the requirements for them is the ability to work in conditions of uncertainty. Methods of pedagogical design taking into account cognitive styles of personality in the process of professional training of future software engineers are offered.

Conclusions. Professional training of future software engineers in a modern student-centered educational environment is based on individual qualities and cognitive processes of the individual. In addition, attention to cognitive styles of personality is increased as the sustainable ways of handling information are essential for successful activities in the information society. The relationship between the cognitive styles of the individual and the effectiveness of its activities is currently insufficiently studied, so there are a number of problems in the educational process that need to be addressed to achieve the goals of quality training of future software engineers. Based on the analysis of scientific 
publications and our own experience, we can offer the following approaches to taking into account the cognitive styles of higher education: building an educational process based on the formed cognitive styles for the formation of new knowledge; grouping students with different styles to work together; creating situations for the manifestation of atypical for the individual models of intellectual behavior.

Keywords: cognitive style; future software engineer; higher education student; master's level of higher education; professional training.

\section{References}

1. Koval, I.V. (2018). Kohnityvni styli yak indyvidualnopsykholohichni peredumovy ovolodinnia inozemnoiu movoiu u vyshchomu navchalnomu zakladi [Cognitive styles as individual psychological preconditions for mastering a foreign language at the university]. Problemy suchasnoi psykholohii - Problems of Modern Psychology, 40, 174-184. DOI: https://doi.org/ 10.32626/2227-6246.2018-40.174-184 [in Ukrainian].

2. Kruhlyk, V. (2016). Problema onovlennia profiliv osvitnikh prohram pidhotovky inzheneriv-prohramistiv [The Problem of Updating the Profile of Educational Training Programs for Software Engineers]. Molod i rynok - Youth and Market, 7(138), 89-93 [in Ukrainian].

3. Maksymenko, S.D. \& Pasichnyk, I.D. (2010). Rol kohnityvno-stylovykh osoblyvostei osobystosti v protsesi navchalnoi diialnosti [The role of cognitive and stylistic features of the individual in the learning process]. Naukovi zapysky [Natsionalnoho universytetu "Ostrozka akademiia»]. Seriia : Psykholohiia i pedahohika - Scientific notes [National University "Ostroh Academy»]. Series: Psychology and pedagogy, 14, 3-10 [in Ukrainian].

4. Popova, M. (2019). Znachushchist kohnityvnykh styliv dlia riznykh sfer profesiinoi diialnosti [The Importance of Cognitive Styles for Different Spheres of Professional Activities]. Problemy 
suchasnoi psykholohii - Problems of Modern Psychology, 46, 308-326. DOI: https://doi.org/10.32626/2227-6246.2019-46.308326 [in Ukrainian].

5. Pro zatverdzhennia Natsionalnoi ramky kvalifikatsii : Postanova Kabinetu Ministriv Ukrainy vid 23.11.2011 r. № 1341 (zi zminamy). [On approval of the National Qualifications Framework : Resolution of 23.11.2011 No. 1341 (as amended)]. URL: https://zakon.rada.gov.ua/laws/show/1341-2011-п. [in Ukrainian]

6. Holodnaya, M.A. (2004). Kognitivnyie stili. O prirode individualnogo uma [Cognitive Styles. On the nature of the individual mind]. Saint-Petersburg: Piter [in Russian].

7. Matsumoto, D. (Ed.). (2009). The Cambridge Dictionary of Psychology. New York : Cambridge University Press.

\section{Вступ}

Інформаційне суспільство висуває високі вимоги до випускників закладів вищої освіти, які здобули освітній ступінь магістра. Ці вимоги узагальнено сформульовано в Національній рамці кваліфікацій (Про затвердження Національної рамки кваліфікацій, 2011), сьомому рівню якої відповідає кваліфікація магістра. Такі спеціалісти зокрема повинні мати «здатність інтегрувати знання та розв' язувати складні задачі ..., здатність розв’язувати проблеми у нових або незнайомих середовищах за наявності неповної або обмеженої інформації» й ін. (Про затвердження Національної рамки кваліфікацій, 2011). Отже, важливе значення має здатність використовувати наявні знання та уміння в нових ситуаціях, в умовах невизначеності й надмірної інформації на основі отримання та обробки даних 3 навколишнього середовища.

У процесі формування та розвитку цієї здатності, спираючись на положення студентоцентрованого підходу, слід враховувати особисті якості (темперамент, мотивація, здібності й ін.), особливості пізнавальних процесів 
здобувачів освіти (пам'яті, мислення, уваги й ін.), а також притаманні їм способи оперування інформацією. Це узгоджується з поглядами науковців, що якість професійної підготовки залежить зокрема від індивідуальнопсихологічних характеристик та особливостей пізнавальних процесів людини (Максименко, Пасічник, 2010; Попова, 2019).

Такі «характерні моделі обробки інформації, включаючи сприйняття, свідомі міркування, запам'ятовування, вирішення проблем та розуміння світу загалом» називають когнітивними стилями (The Cambridge Dictionary of Psychology, 2009 : 117). Вони представляють собою достатньо стійкі індивідуальні способи обробки інформації та взаємодії з інформаційним полем (Коваль, 2018 : 179). Важливим також є той факт, що кожна людина може проявляти різні стильові ознаки залежно від ситуації діяльності, тобто володіє різними когнітивними стилями (Коваль, 2018 : 181).

Проблема когнітивних стилів, їх вивчення та урахування в навчальній та професійній діяльності фахівців різних спеціальностей достатньо добре представлена у вітчизняних та закордонних наукових публікаціях, у першу чергу в галузі психології. Особливості прояву когнітивних стилів у діяльності IT-фахівців і зокрема програмістів досліджували переважно закордонні науковці: Ж. Л. Вілсон; Н. С. Грант; Л. Ф. Капрез і Ф. Ахмед; Дж. П. Маєрс і Б. Мюнзінгер; Дж. ван Мерієнбор; Г. Д. Стерлінг і

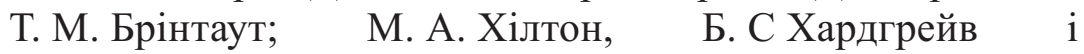
Д. Дж. Армстронг й ін.

Провадження ефективної підготовки майбутніх інженерів-програмістів за освітніми програмами магістерського рівня, зокрема зі спеціальності «Комп’ютерні науки», вимагає посиленої уваги до їх когнітивних стилів здобувачів вищої освіти, оскільки їхня професійна діяльність передбачає виконання різноманітних операцій 3 
інформацією.

Сучасний програміст повинен розумітися на нових технологіях та методиках розв'язання професійних завдань, підтримувати на високому рівні свій професіоналізм, бути здатним до самостійного навчання протягом усього життя, швидко адаптуватися до змінюваних умов діяльності та приймати необхідні рішення стосовно як власних, так i колективних дій (Круглик, 2016 : 92).

Успішне виконання виробничих завдань в ІТ-галузі великою мірою залежить від когнітивного стилю особистості та ситуації, в якій цей стиль проявляється. Отже, для забезпечення ефективної діяльності та професійної самореалізації програміста зовнішні умови повинні максимально сприяти прояву його специфічних способів сприйняття, обробки та використання інформації. У зв'язку з цим у процесі професійної підготовки майбутніх інженерівпрограмістів за освітніми програмами магістерського рівня постає низка проблемних питань: чи існує безпосередній зв'язок між навчальною успішністю студентів та їх когнітивними стилями; як визначити когнітивні стилі здобувачів вищої освіти; як сформувати в них розуміння власних моделей обробки інформації та уміння ефективно застосовувати їх у конкретних практичних ситуаціях; якою мірою необхідно враховувати когнітивні стилі в ситуації навчання та наскільки освітнє середовище має відповідати цим стилям; якому підходу віддати перевагу - створенню максимально сприятливих умов для прояву когнітивних стилів майбутніх інженерів-програмістів або умов для формування інших моделей взаємодії з інформацією.

Різні аспекти професійної підготовки майбутніх ITфахівців та інженерів-програмістів у закладах вищої освіти розкрито в дослідженнях I. Бардус, М. Вінника, С. Конюхова, В. Круглика, В. Осадчого, 3. Сейдаметової, С. Семерікова, А. Стрюка, Д. Щедролосьєва й інших науковців. Проте, незважаючи на значну кількість наукових публікацій, 
проблема співвідношення когнітивних стилів майбутніх інженерів-програмістів 3 їх навчальною успішністю у процесі професійної підготовки за освітніми програмами магістерського рівня з огляду на їі багатоаспектність наразі недостатньо досліджена. На нашу думку це пов'язано зокрема із загальною методологічною проблемою, яку сформулювали С. Максименко та Д. Пасічник: «чи можуть когнітивні стилі визначати не тільки способи діяльності, але й iï продуктивність, успішність, результативність» (Максименко, Пасічник, 2010 : 6).

Mema cmammi - визначити підходи до урахування когнітивних стилів майбутніх інженерів-програмістів у процесі професійної підготовки за освітніми програмами магістерського рівня.

\section{Матеріал і методи досліджень}

Основу нашого дослідження становлять публікації вітчизняних та закордонних науковців, присвячені проблемам визначення когнітивних стилів особистості та їх зв'язку 3 практичною діяльністю людини. Також ми спиралися на емпіричні матеріали, отримані у процесі вивчення особливостей професійної підготовки майбутніх інженерів програмістів за освітніми програмами магістерського рівня, зокрема зі спеціальності «Комп’ютерні науки».

Основні методи дослідження: пошук i відбір релевантних статей за проблемою дослідження в пошуковій системі Google Scholar та бібліографічній реферативній базі даних Scopus; аналіз і узагальнення наукових публікацій; вивчення освітнього процесу.

\section{Результати та їхнс обговорення}

Важливим напрямом сучасних психолого-педагогічних досліджень є вивчення особистості як споживача інформації, «яка певним чином декодується, переробляється, інтерпретується та використовується для досягнення кінцевого результату діяльності» (Максименко, Пасічник, 
2010 : 4). Це пов'язано 3 тим, що в інформаційному суспільстві будь-яка діяльність висуває певні вимоги до способів опрацювання інформації людиною, тому іiі успішність залежить зокрема і від когнітивного стилю особистості (Попова, $2019: 310$ ).

За визначенням М. Холодної «когнітивні стилі - це індивідуально-своєрідні способи переробки інформації про своє оточення у вигляді індивідуальних відмінностей у сприйнятті, аналізі, структуруванні, категоризації, оцінюванні того, що відбувається» (Холодная, 2004 : 38). Когнітивні стилі координують взаємодію пізнавальних процесів особистості, відображують індивідуальні способи сприйняття та аналізу стимулів середовища, тому $\epsilon$ причиною різного розуміння й оцінювання ситуацій різними людьми (Коваль, 2018 : 180).

Психологічний феномен когнітивного стилю має низку характерних ознак, зокрема: 1) когнітивний стиль характеризує особливості організації пізнавальної сфери і не має прямого відношення до особливостей іiі змісту; 2) когнітивний стиль - це інструментальна характеристика інтелектуальної діяльності, яку можна протиставити іiі продуктивній характеристиці; 3) когнітивний стиль $\epsilon$ біполярним психологічним виміром, тобто має два полюси дві крайні форми інтелектуальної поведінки; 4) до когнітивних стилів немає сенсу застосовувати оціночні судження, оскільки кожний полюс може сприяти ефективній індивідуальній адаптації залежно від ситуації діяльності; 5) когнітивний стиль - це стійка характеристика суб'єкта, що стабільно виявляється на різних рівнях інтелектуального функціонування і в різних ситуаціях; 6) когнітивний стиль це надання переваги певному способу інтелектуальної поведінки (тобто суб'єкт в умовах свободи вибору обирає той спосіб сприйняття та аналізу ситуації, який найбільше відповідає його психологічним можливостям) (Холодная, $2004: 40)$. 
Найчастіше виділяють такі когнітивні стилі, як-от: полезалежність / поленезалежність, вузький / широкий діапазон еквівалентності; вузькість / широта категорії; ригідний / гнучкий пізнавальний контроль; толерантність / нетолерантність до нереалістичного досвіду; фокусуючий / скануючий контроль; згладжування / загострення; імпульсивність / рефлективність; конкретна / абстрактна концептуалізація; когнітивна простота / складність (Холодная, 2004 : 45).

Слід враховувати, що необхідність дотримання жорстких правил або обмежений вибір способів діяльності призводить до значного ускладнення формування та прояву індивідуального стилю людини, зокрема когнітивного (Коваль, 2018 : 178).

Сучасне студентоцентроване освітнє середовище здебільшого не має жорстких обмежень на способи діяльності. Отже, майбутні інженери-програмісти, які навчаються за освітніми програмами магістерського рівня, мають можливість розв'язувати навчальні і професійні завдання, спираючись на вже сформовані в них когнітивні стилі, що сприяє формуванню нових розумінь і знань, розвитку наукового світогляду й фахового кругозору. Освітній процес доцільно будувати з опорою на провідні способи інтелектуальної поведінки в межах дисциплін, які можуть вимагати від студентів розумових зусиль та формування нетривіальних підходів до вирішення завдань, наприклад «Експертні технології для систем підтримки прийняття рішень», «Нейронні мережі» або «Сучасні проблеми штучного інтелекту». Іншим варіантом урахування когнітивних стилів $€$ об'єднання студентів 3 різними стильовими особливостями в мікрогрупи для виконання навчальних проєктів для досягнення синергії.

Разом $з$ тим, схарактеризовані вище вимоги до фахівців, які здобули освітній ступінь магістра, зумовлюють актуальність підготовки майбутніх інженерів-програмістів до діяльності в ситуаціях, коли необхідно виявляти різні 
способи взаємодії з інформаційним полем, зокрема ті, що не властиві конкретній особистості. 3 цією метою вважаємо доцільним у межах дисциплін, фундамент професійної підготовки у студентів вже сформовано (наприклад, «Розробка мобільних додатків», «Сучасні веб-технології», «Управління програмними проектами», «Комп'ютерний аналіз даних» й ін.), створювати більш складні умови, що спонукатимуть їх до застосування незвичних моделей інтелектуальної поведінки. Наведемо деякі приклади.

Психологічні дослідження показали, що поленезалежні студенти краще виявляють структуру текстів та реорганізують їх, результатом чого є побудова чітких ієрархій понятійної інформації навчальних дисциплін (Максименко, Пасічник, 2010 : 8). Для поле залежних здобувачів така діяльність здебільшого становить значну проблему, тому доцільно пропонувати їм завдання на побудову діаграм зв'язків, прецедентів й ін., складання структурно-логічних схем на основі лекційного матеріалу, написання квінтесенцій досліджень тощо.

Когнітивний стиль «вузький / широкий діапазон еквівалентності» характеризує індивідуальні відмінності в орієнтації на подібність або відмінність об'єктів у процесі їх категоризації. Узагальнено цей стиль можна схарактеризувати так: вузький діапазон еквівалентності мають особи, які поділяють об’єкти на багато груп невеликого об'єму; широкий - особи, які виділяють мало груп великого об'єму (Холодная, 2004 : 60). 3 урахуванням цього можна у процесі постановки завдань встановлювати жорсткі вимоги до класифікації певних об'єктів, наприклад: створити типологію засобів створення інтерфейсу користувача мобільних додатків у середовищі Android Studio, взяти за основу групування за трьома ознаками. Інший варіант завдання: розробити мобільний додаток «Калькулятор», використовуючи для створення інтерфейсу 10 елементів керування; обгрунтувати своє рішення, якщо кількість елементів не дорівнює 10. 
До когнітивних стилів, вплив яких на успішність навчальної та професійної діяльності є найбільш очевидним, належить імпульсивність / рефлективність в умовах невизначеності, коли треба зробити вибір 3 множини альтернатив. Імпульсивні особи схильні реагувати швидко і висувати гіпотези без аналізу альтернатив. Рефлективні особи реагують повільно, попередньо формулюючи i перевіряючи багато альтернативних гіпотез (Холодная, 2004 : 79). Враховуючи це, імпульсивним здобувачам варто пропонувати обов'язково сформулювати декілька альтернативних рішень одного завдання, навіть якщо перший виявився вдалим. Для рефлективних студентів навпаки можна обмежити час пошуку та кількість аналізованих альтернатив.

Зауважимо, що застосування кожного 3 названих підходів може призвести до тимчасового зниження навчальної успішності здобувачів вищої освіти, оскільки вони повинні будуть діяти в нетиповий спосіб. Проте у віддаленій перспективі вони сприятимуть пізнанню студентами власних особистостей, а також формуванню в них здатності адаптуватися до нових обставин. Однак досягнення такого результату можливо лише за умови попереднього педагогічного моделювання.

\section{Висновки}

За результатами проведеного дослідження можна сформулювати такі основні висновки:

1. Професійна підготовка майбутніх інженерівпрограмістів у сучасному студентоцентрованому освітньому середовищі спирається на урахування індивідуальних якостей та пізнавальних процесів особистості. Окрім того, посилюється увага до когнітивних стилів особистості, оскільки стійкі способи оперування інформацією мають суттєве значення для успішної діяльності в умовах інформаційного суспільства.

2. Зв'язок між когнітивними стилями особистості та ефективністю іï діяльності наразі недостатньо досліджений, 
тому в освітньому процесі постає низка проблем, які потребують вирішення для досягнення цілей якісної підготовки майбутніх інженерів-програмістів.

3. На основі аналізу наукових публікацій та власного досвіду ми можемо запропонувати такі підходи до урахування когнітивних стилів здобувачів вищої освіти: побудова освітнього процесу 3 опорою на сформовані когнітивні стилі для формування нового знання; об'єднання студентів з різними стильовими установками у групи для спільної роботи; створення ситуацій для прояву нетипових для особистості моделей інтелектуальної поведінки.

\section{Література}

1. Коваль І.В. Когнітивні стилі як індивідуальнопсихологічні передумови оволодіння іноземною мовою у вищому навчальному закладі. Проблеми сучасної психології. 2018. Вип. 40. С. 174-184. DOI: https://doi.org/10.32626/22276246.2018-40.174-184.

2. Круглик В. Проблема оновлення профілів освітніх програм підготовки інженерів-програмістів. Молодь і ринок. 2016. № 7(138). С. 89-93.

3. Максименко С.Д., Пасічник І.Д. Роль когнітивностильових особливостей особистості в процесі навчальної діяльності. Наукові записки [Національного університету «Острозька академія»]. Серія : Психологія і педагогіка. 2010. Вип. 14. С. 3-10.

4. Попова М. Значущість когнітивних стилів для різних сфер професійної діяльності. Проблеми сучасної психології. 2019. Вип. 46. С. 308-326. DOI: https://doi.org/10.32626/22276246.2019-46.308-326.

5. Про затвердження Національної рамки кваліфікацій : Постанова Кабінету Міністрів України від 23.11.2011 р. № 1341 (зі змінами). URL: https://zakon.rada.gov.ua/ laws/show/ 1341-2011-п.

6. Холодная М.А. Когнитивные стили. О природе индивидуального ума. Санкт-Петербург : Питер, 2004. 384 с. 
7. The Cambridge Dictionary of Psychology / D. Matsumoto (Ed.). New York : Cambridge University Press, 2009. 606 p.

Сендер А. А.

Підходи до урахування когнітивних стилів у процесі професійної підготовки майбутніх інженерів-програмістів

\section{Анотація}

У статті представлено результати дослідження, спрямованого на аналіз психологічного феномена «когнітивний стиль особистості». На основі вивчення літературних джерел встановлено, що когнітивний стиль представляє собою усталені індивідуальні способи інтелектуальної поведінки особистості. Показано, що урахування когнітивних стилів має важливе значення для досягнення цілей підготовки майбутніх інженерівпрограмістів за освітніми програмами магістерського рівня, оскільки однією з вимог до них є здатність до діяльності в умовах невизначеності. Запропоновано способи урахування когнітивних стилів в освітньому процесі.

Ключові слова: когнітивний стиль; майбутній інженерпрограміст; здобувач вищої освіти; магістерський рівень вищої освіти; професійна підготовка.

Сендер А. А.

Подходы к учету когнитивных стилей в процессе профессиональной подготовки будущих инженеровпрограммистов

\section{Аннотация}

В статье представлены результаты исследования, направленного на анализ психологического феномена «когнитивный стиль личности». На основе изучения 
литературных источников установлено, что когнитивный стиль представляет собой устоявшиеся индивидуальные способы интеллектуального поведения личности. Показано, что учет когнитивных стилей имеет важное значение для достижения целей подготовки будущих инженеровпрограммистов по образовательным программам магистерского уровня, поскольку одним из требований к ним является способность к деятельности в условиях неопределенности. Предложены способы учета когнитивных стилей в образовательном процессе.

Ключевые слова: когнитивный стиль; будущий инженер-программист; соискатель высшего образования; магистерский уровень высшего образования; профессиональная подготовка. 